\title{
Effect of Soybean Growth Stage at the Time of Inoculation with Diaporthe phaseolorum var. meridionales on Stem Canker Development and Yield
}

\author{
J. C. Rupe, Associate Professor, E. A. Sutton, Former Research Specialist, and C. M. Becton, Research Specialist, \\ Department of Plant Pathology, University of Arkansas, Fayetteville 72701; and E. E. Gbur, Jr., Professor, Agri- \\ cultural Statistics Laboratory, University of Arkansas, Fayetteville 72701
}

\begin{abstract}
Rupe, J. C., Sutton, E. A., Becton, C. M., and Gbur, E. E., Jr. 1999. Effect of soybean growth stage at the time of inoculation with Diaporthe phaseolorum var. meridionales on stem canker development and yield. Plant Dis. 83:582-586.

Infections at early stages of plant development followed by a long incubation period before symptoms appear during reproductive stages is characteristic of the disease cycle of stem canker of soybean, caused by Diaporthe phaseolorum var. meridionales. To determine the effect of plant growth stage at the time of infection on symptom development and yield components, soybean plants (cv. Walters) were grown in microplots and inoculated with a suspension of ascospores $\left(10^{6} / \mathrm{ml}\right)$ at the $\mathrm{V}_{1}, \mathrm{~V}_{4}, \mathrm{~V}_{6}, \mathrm{~V}_{10}$, or $\mathrm{R}_{2}$ growth stage. Noninoculated plants served as controls. Development of foliar symptoms was quantified weekly after flowering $\left(\mathrm{R}_{2}\right)$, and yields and seed weights were determined. The experiment was conducted twice, in 1992 and 1994. Foliar symptoms of stem canker developed for all treatments except the noninoculated control. Foliar symptoms appeared at the $\mathrm{R}_{2}$ to $\mathrm{R}_{5}$ growth stage and reached 90 to $100 \%$ incidence for most treatments. Disease development was delayed for the $\mathrm{R}_{2}$ inoculation, suggesting that a minimum incubation period of 34 to 41 days is necessary before foliar symptoms develop. Disease (area under the disease progress curve) was greater and yield, seed number, and seed weight were less in 1994 than in 1992. Quadratic equations significantly related these variables to time of inoculation and reached maximum or minimum values between 40.9 and 43.3 days after planting. This corresponded to the $\mathrm{V}_{6}$ growth stage. Yield and seed number were affected by disease development during pod formation $\left(R_{2}\right.$ to $\left.R_{5}\right)$ in both years, while yield and seed weight were affected by disease development during seed formation $\left(R_{5}\right.$ to $\left.R_{6}\right)$ in 1992 .
\end{abstract}

Southern stem canker, caused by Diaporthe phaseolorum (Cooke \& Ellis) Sacc. var. meridionales F.A. Fernandez (6), causes severe yield losses of soybean (Glycine $\max$ (L.) Merr.) in the southern United States and South America (11). This disease produces an elongated, brown canker on the stem that is centered around a lower node. The canker rarely girdles the stem, but it appears to damage the plant by producing a toxin that results in distinctive foliar symptoms (8). These symptoms begin as interveinal chlorotic streaks that become necrotic, killing the leaf, which remains attached to the stem. Diseased plants soon die, and yields are significantly reduced. While these symptoms of stem canker appear during reproductive development, they are the result of infections that occurred during early vegetative growth $(1,10,16)$. The importance of early

Corresponding author: J. C. Rupe

E-mail: jrupe@comp.uark.edu

Published with the approval of the Director, Arkansas Agricultural Experiment Station, manuscript 98079.

Accepted for publication 22 March 1999.

Publication no. D-1999-0419-03R

(C) 1999 The American Phytopathological Society infection was demonstrated by the disease control achieved with fungicides applied during vegetative stages of growth $(1,2,16)$ and in field evaluations of soybean cultivars that used inoculations during early vegetative growth stages to initiate stem canker epidemics $(10,13,14,17)$. Smith and Backman found that the greatest disease incidence occurred following application of infested debris at $\mathrm{V}_{3}$. Disease incidence decreased rapidly thereafter for later applications (16). Only the most susceptible cultivars developed symptoms following applications of infested debris after $\mathrm{V}_{10}$, and no symptoms developed in cultivars exposed to infested debris after the onset of reproductive development $\left(\mathrm{R}_{1}\right)$. The early application corresponded to the observed ascospore release which they reported to occur from late April to June in the southern United States (16).

Different results have been reported when plants were inoculated. Ploetz and Shokes inoculated plants from $V_{1}$ to $V_{11}$ in the greenhouse with either ascospores or conidia and found that symptoms developed no sooner than the $\mathrm{R}_{2}$ stage and following an incubation period of 50 to 80 days (12). Pacumbaba inoculated soybeans at $R_{1}$ with a mycelial suspension and observed symptoms at $R_{5}(9)$. The incubation period was not given. Damicone et al. reported that 55 to 105 days were required for symptoms to appear on plants inoculated at $V_{5}$ in the greenhouse following exposure to different surface wetness regimes (3). Plants in the study were first evaluated for disease at the $R_{4}$ growth stage. In a field study using naturally infested soybean debris and artificially infested oat grains, cankers first appeared at $\mathrm{R}_{1}$ in 1986, but at $\mathrm{V}_{10}$ in 1987 (4). These growth stages occurred 49 and 56 days after planting, respectively. Disease progress in this test fit the monomolecular model of disease progress, suggesting a monocyclic disease typical of diseases occurring from a fixed source of inoculum such as infested debris. They did not evaluate the development of foliar symptoms. Conversely, Subbarao et al. found that disease progress curves fit a logistic equation, suggesting a polycyclic disease with inoculum increasing during the season (19). They observed pycnidia and perithecia on plant parts after $R_{1}$, which may have been the source of secondary inoculum. They also reported that greenhouse inoculations from $R_{2}$ to $R_{5}$ resulted in disease development, but they did not report on the incubation periods.

The objectives of this study were to determine the relationship of time of infection to development of foliar symptoms of stem canker, and the effect of disease on soybean yield. An initial report has been published (20).

\section{MATERIALS AND METHODS}

The test was conducted at the University of Arkansas experiment farm, Fayetteville, Arkansas, in 1992 and 1994. Seeds of the stem canker susceptible cultivar Walters (7) were sown in pasteurized soil in 208liter plastic barrel microplots (diameter 60 $\mathrm{cm}$, height $100 \mathrm{~cm}$ ). After emergence, the microplots were thinned to 10 seedlings per microplot.

An ascospore suspension of D. phaseolorum var. meridionales was produced from a single-spore culture isolated from a diseased plant in southwestern Arkansas. Senescent soybean stem segments (3 to 4 $\mathrm{cm}$ long) were soaked in deionized water for $30 \mathrm{~min}$ and sterilized by autoclaving for $45 \mathrm{~min}$ on 2 successive days. Two to four of these sterilized stem segments were placed in 9-cm plastic petri dishes, and potato dextrose agar (PDA) (Difco Laboratories, Detroit, MI) was added. A 0.5$\mathrm{cm}$-diameter agar disk plus mycelium was 
placed in the center of each plate, which were sealed (Parafilm, American National Can, Greenwich, CT) and incubated at room temperature $\left(22^{\circ} \mathrm{C}\right)$ and ambient light for 6 to 8 weeks to produce ascospores. Ascospores were collected by flooding the plate with deionized water and rubbing the surface of the stem segments with a metal spatula. The resulting suspension was filtered through four layers of cheesecloth. The plates were reflooded, and the procedure was repeated. Inoculum concentration was adjusted to $10^{6}$ ascospores per $\mathrm{ml}$ using a hemacytometer, and $1 \mathrm{ml}$ of Tween 20 per liter was added as a surfactant.

To determine the effect of inoculation timing on disease development, plants were inoculated at the $\mathrm{V}_{1}, \mathrm{~V}_{4}, \mathrm{~V}_{6}, \mathrm{~V}_{10}$, or $\mathrm{R}_{2}$ growth stage or not inoculated (5). Soybean growth stages are divided into vegetative (designated by $\mathrm{V}$ with a numbered subscript indicating the number of nodes above the unifoliate node) and reproductive (designated by $\mathrm{R}$ with a numbered subscript). The reproductive stages were $\mathrm{R}_{1}$ (beginning bloom), $\mathrm{R}_{2}$ (full bloom), $\mathrm{R}_{3}$ (beginning pod, pod $5 \mathrm{~mm}$ long), $\mathrm{R}_{4}$ (full pod, pod $2 \mathrm{~cm}$ long), $\mathrm{R}_{5}$ (beginning seed, seed $3 \mathrm{~mm}$ long), $\mathrm{R}_{6}$ (full seed, seed fills locule), $\mathrm{R}_{7}$ (beginning maturity, physiological maturity), and $\mathrm{R}_{8}$ (harvest maturity). Plants were sprayed with inoculum until runoff, and large white plastic bags were placed over each inoculated microplot and secured with adhesive tape. The bags were removed after 3 days. Dates and days after planting (DAP) of each treatment in each year are presented in Table 1.

Beginning at full flower $\left(\mathrm{R}_{2}\right)$, disease incidence and plant growth stage were assessed weekly. A plant was considered diseased if foliar symptoms of stem canker appeared on one or more leaves. Ratings were taken until the plants reached physiological maturity $\left(\mathrm{R}_{7}\right)$. Yields and weight of 100 seed were taken from each microplot and expressed as dry weight $(0 \%$ moisture). The total seed per plot was calculated from the yield and 100 seed weight.

The experiment was conducted as a randomized complete block design with growth stage at inoculation as the treatment. There were five replicates, and the experiment was conducted twice, in 1992 and 1994.

Analysis. Area under the disease progress curve (AUDPC) was calculated for each treatment (15). AUDPC, yield, seed weight, and seed number were individually related to time of inoculation with quadratic equations. Results were analyzed over years to allow statistical comparisons between years.

To further relate disease development to yield, disease progress was divided into three sections: the proportion of plants that became diseased from $R_{2}$ to $R_{5}$ (the period from flowering to the beginning of seed development); the proportion of plants that became diseased from $\mathrm{R}_{5}$ to $\mathrm{R}_{6}$ (the period of major seed development); and the proportion of plants that became diseased from $R_{6}$ to $R_{7}$ (the period after the seed fills the seed locule until physiological maturity). Disease was related to yield, seed weight, and seed number with multiple regression. Yields of the uninoculated control plants were not used in any analysis.

All statistical analyses were carried out using SAS Version 6.12 (SAS Inc., Cary,

Table 1. Dates, growth stage, and days after planting (DAP) of soybean (cv. Walters) grown in microplots in 1992 and 1994

\begin{tabular}{|c|c|c|c|c|}
\hline \multirow{2}{*}{$\begin{array}{l}\text { Growth } \\
\text { stage }^{\mathrm{a}}\end{array}$} & \multicolumn{2}{|c|}{1992} & \multicolumn{2}{|c|}{1994} \\
\hline & Date & DAP & Date & DAP \\
\hline Planting & 11 May & 0 & 2 May & 0 \\
\hline $\mathrm{V}_{1}$ & 26 May & 15 & 19 May & 17 \\
\hline $\mathrm{V}_{4}$ & 11 June & 31 & 2 June & 31 \\
\hline$V_{6}$ & 18 June & 38 & 10 June & 39 \\
\hline $\mathrm{V}_{10}$ & 8 July & 58 & 27 June & 56 \\
\hline $\mathrm{R}_{2}$ & 28 July & 78 & 19 July & 78 \\
\hline $\mathrm{R}_{3}$ & 14 August & 95 & 27 July & 86 \\
\hline $\mathrm{R}_{4}$ & 24 August & 105 & 15 August & 105 \\
\hline $\mathrm{R}_{5}$ & 1 September & 113 & 22 August & 112 \\
\hline $\mathrm{R}_{6}$ & 22 September & 134 & 5 September & 126 \\
\hline $\mathrm{R}_{7}$ & 29 September & 141 & 12 September & 133 \\
\hline
\end{tabular}

${ }^{a}$ Soybean growth stages as described by Fehr et al. (5).

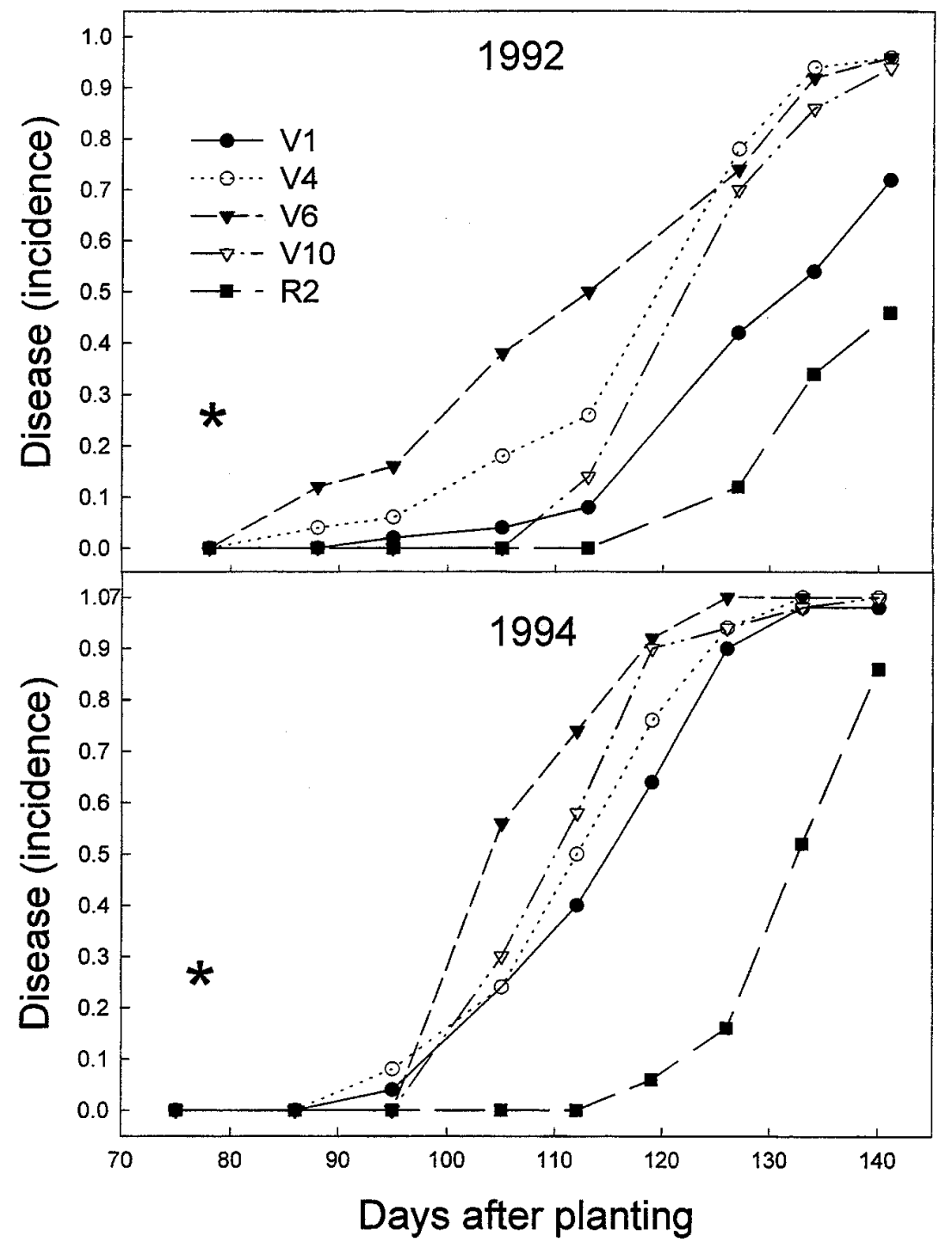

Fig. 1. Proportion of plants with stem canker foliar symptoms resulting from inoculations with Diaporthe phaseolorum var. meridionales at either the $\mathrm{V}_{1}, \mathrm{~V}_{4}, \mathrm{~V}_{6}, \mathrm{~V}_{10}$, or $\mathrm{R}_{2}$ growth stage in microplots in 1992 and 1994. Flowering $\left(\mathbf{R}_{2}\right)$ date is signified by an asterisk $(*)$. 
NC). All differences that were designated significant were statistically significant at $P<0.05$.

\section{RESULTS}

Foliar symptoms of stem canker first appeared after flowering $\left(\mathrm{R}_{2}\right)$ in both years (Fig. 1). In 1992, foliar symptoms first appeared between 88 and 95 DAP for inoculation at $\mathrm{V}_{1}$, between 78 and 88 DAP for inoculations at $V_{4}$ and $V_{6}$, between 105 and 113 DAP for inoculation at $\mathrm{V}_{10}$, and between 113 and 127 DAP for inoculation at $R_{2}$ (Table 1). In 1994, symptoms first appeared between 86 and 95 DAP for inoculations at $\mathrm{V}_{1}$ and $\mathrm{V}_{4}$, between 95 and 105 DAP for inoculations at $\mathrm{V}_{6}$ and $\mathrm{V}_{10}$, and between 112 and 119 DAP for inoculation at $R_{2}$. Inoculations at $V_{1}$ had the longest incubation period in both years, between 73 and 80 and between 69 and 78 days in 1992 and 1994, respectively. Inoculations at $\mathrm{R}_{2}$ had the shortest incubation period, between 35 and 49 and between 34 and 41 days in 1992 and 1994, respectively. Stem canker did not develop in the uninoculated treatment in either year.

For inoculations during the vegetative stages of growth, stem canker progressed fastest following the $V_{6}$ inoculation and slowest following the $V_{1}$ inoculation (Fig. 1). Disease onset following the inoculation at $R_{2}$ was delayed in both years until $R_{5}$
(Fig. 1, Table 1). Excluding the inoculation at $\mathrm{R}_{2}$, disease incidence at $\mathrm{R}_{5}$ ranged from 8 to $50 \%$ in 1992 and from 44 to $74 \%$ in 1994. There was little increase in disease after $\mathrm{R}_{6}$ for the inoculations at $\mathrm{V}_{4}$ through $\mathrm{V}_{10}$ in 1992 and at $\mathrm{V}_{1}$ through $\mathrm{V}_{10}$ in 1994.

At each inoculation time, AUDPC was higher and yield, seed weight, and seed number were lower in 1994 than in 1992 (Fig. 2). These data were significantly related to the time of inoculation with quadratic equations $(P=0.0004,0.0002$, 0.0005 , and 0.0248 for AUDPC, yield, seed weight, and seed number, respectively). For all four dependent variables, the quadratic equations had the same coefficients for DAP and $\mathrm{DAP}^{2}$ but significantly different intercepts for the 2 years (Table 2). Based on these equations, the estimated maximum or minimum values for all of these factors ranged from 40.9 to 43.3 DAP.

To further understand the effect of disease development on yield, the effect of disease development at different reproductive stages was determined using multiple regression on data from both years separately. In 1992, disease that developed from $R_{2}$ to $R_{5}$ (period from flowering to the beginning of seed formation) and disease that developed between $R_{5}$ and $R_{6}$ (major period of seed development) were significantly related to both yield and seed weight (Table 3). Seed number was significantly related to disease that developed from $\mathrm{R}_{2}$ to $\mathrm{R}_{5}$ only. In 1994 , yield and seed number were significantly related to disease that developed from $R_{2}$ to $R_{5}$ only. Yield, seed weight, and seed number were not related in either year to disease that developed between $R_{6}$ and $R_{7}$ (the period after the seed fills the locule until physiological maturity).

\section{DISCUSSION}

Development of foliar symptoms of stem canker depends on two things: soybean reproductive development and a minimum incubation period. Regardless of growth stage at the time of inoculation, foliar symptoms did not develop until the onset of flowering $\left(\mathrm{R}_{2}\right)$. This agrees with previous reports $(1,9,12)$ except for that of Damicone et al. (4), who reported symptoms at $\mathrm{V}_{10}$. In the latter report, they measured only canker formation, which probably occurred before foliar symptoms. However, canker appearance was still associated with flowering, since cankers appeared 56 days after planting in the second year of the study and 49 days after planting in the first year, when the plants were at $\mathrm{R}_{1}$.

Besides being in reproductive development, there appears to be a minimum incubation period before foliar symptoms de-
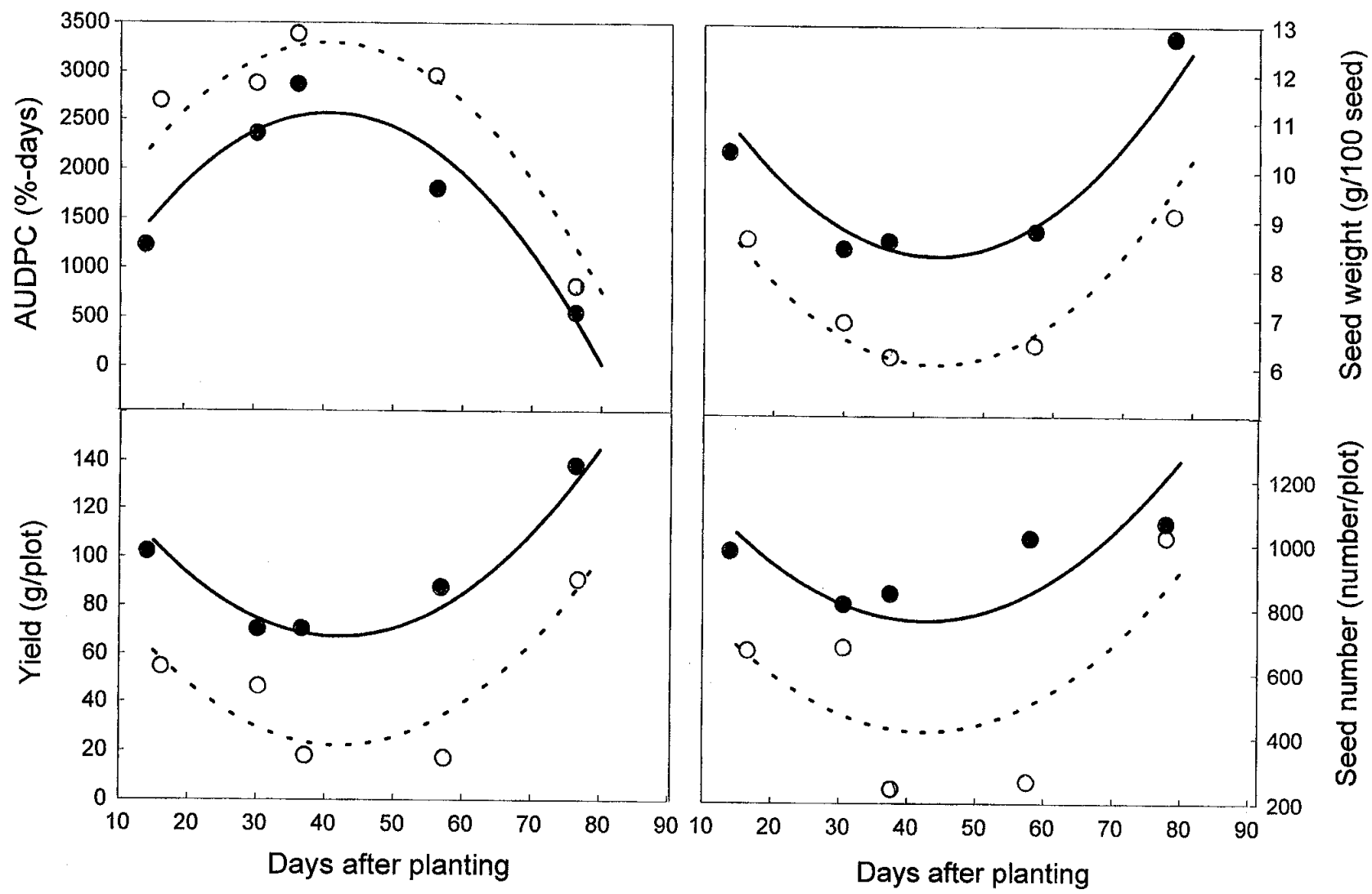

Fig. 2. Relationship of the number of days after planting that plants were inoculated with ascospores of Diaporthe phaseolorum var. meridionales and development of stem canker (area under the disease progress curve [AUDPC]), yield, seed weight, and seed number in 1992 (solid line and solid circles) and 1994 (dashed line and open circles). Circles represent means of each treatment, and lines represent estimated values from fitted quadratic equations. 
velop. In our study, the earliest that symptoms occurred was between 34 and 41 days after inoculation when inoculated at $R_{2}$. Because of the need for plants to be in reproductive development, symptoms appeared in the other inoculated treatments after longer periods of time following inoculation, with the $\mathrm{V}_{1}$ inoculation taking the longest. In other studies, a minimum of 50 to 55 days after inoculation were required to develop symptoms in greenhouse inoculations $(3,12)$. The length of this incubation period may be influenced by the amount of infection. Damicone et al. (3) reported that the appearance of first symptoms was related to the duration of surface moisture at the time of infection: the longer the surface moisture period and, shorter the incubation period. This may explain differences in disease progress between the 2 years. Greater infection in 1994 may have resulted in more rapid disease development for all treatments after presumably, the greater the infection, the

disease onset than in 1992. This difference between years may also reflect different environments. Although temperatures were similar both years, rainfall was 6.4 to 9.5 cm less in 1994 than in 1992 during May, June, July, and September (data not shown) and may have resulted in increased drought stress in 1994. The role of the environment in foliar symptom development after infection has not been determined.

Plant growth stage at the time of inoculation influenced later disease development. As estimated by quadratic equations, the highest level of disease and the lowest yields, seed weights, and seed numbers occurred when the plants were inoculated 40 to 43 days after planting. This corresponds to the $\mathrm{V}_{6}$ growth stage. These results contrast with those of Smith and Backman (16), who reported that the optimum growth stage for infection was $V_{3}$ and that disease declined rapidly at earlier and later growth stages. Only in the most susceptible cultivars did they report disease

Table 2. Quadratic regression equations relating the development of stem canker and yield to time of inoculation $^{\mathrm{a}}$ (days after planting or DAP) of soybean with Diaporthe phaseolorum var. meridionales in microplots in 1992 and 1994, Fayetteville, Arkansas

\begin{tabular}{|c|c|c|c|c|c|c|}
\hline \multirow[b]{2}{*}{ Factor } & \multicolumn{2}{|c|}{ Intercept } & \multicolumn{2}{|c|}{ Coefficient $^{\mathrm{b}}$} & \multirow[b]{2}{*}{$\mathbf{R}^{2}$} & \multirow{2}{*}{$\begin{array}{c}\text { Min.c/max. } \\
\text { values } \\
\text { (DAP) }\end{array}$} \\
\hline & 1992 & 1994 & DAP & DAP $^{2}$ & & \\
\hline $\begin{array}{l}\text { AUDPC } \\
\text { (\%-days) }\end{array}$ & $\begin{array}{l}-208.5 \\
(462.9)^{\mathrm{d}}\end{array}$ & $\begin{array}{c}526.4 \\
(470.5)\end{array}$ & $\begin{array}{l}135.78 \\
(22.00)\end{array}$ & $\begin{array}{c}-1.66 \\
(0.23)\end{array}$ & 0.94 & $\begin{array}{l}40.9 \\
(1.6)\end{array}$ \\
\hline $\begin{array}{l}\text { Yield } \\
\text { (g/plot) }\end{array}$ & $\begin{array}{l}161.8 \\
(16.1)\end{array}$ & $\begin{array}{l}116.6 \\
(16.3)\end{array}$ & $\begin{array}{l}-4.51 \\
(0.16)\end{array}$ & $\begin{array}{c}0.05 \\
(0.01)\end{array}$ & 0.95 & $\begin{array}{l}42.0 \\
(1.6)\end{array}$ \\
\hline $\begin{array}{l}\text { Seed weight } \\
\text { (g/100seed) }\end{array}$ & $\begin{array}{l}14.1 \\
(1.0)\end{array}$ & $\begin{array}{l}11.9 \\
(1.0)\end{array}$ & $\begin{array}{l}-0.27 \\
(0.05)\end{array}$ & $\begin{array}{c}0.003 \\
(0.0004)\end{array}$ & 0.94 & $\begin{array}{l}43.3 \\
(1.6)\end{array}$ \\
\hline $\begin{array}{l}\text { Seed number } \\
\text { (number/plot) }\end{array}$ & $\begin{array}{c}1,410.1 \\
(275.3)\end{array}$ & $\begin{array}{c}1,063.5 \\
(279.8)\end{array}$ & $\begin{array}{c}-30.37 \\
(13.08)\end{array}$ & $\begin{array}{c}0.36 \\
(0.13)\end{array}$ & 0.77 & $\begin{array}{l}42.6 \\
(4.1)\end{array}$ \\
\hline
\end{tabular}

${ }^{a}$ Plants inoculated at 15, 31, 38, 58, and 78 DAP in 1992 and 17, 31, 39, 56, and 78 DAP in 1994 with $10^{6}$ ascospores per $\mathrm{ml}$ of $D$. phaseolorum var. meridionales.

${ }^{\mathrm{b}}$ Regressions significant at $P=0.0004,0.0002,0.0005$, and 0.0248 for AUDPC, yield, seed weight, and seed number, respectively.

${ }^{c}$ Number of DAP that a minimum or maximum value was estimated to occur by the quadratic equation.

${ }^{\mathrm{d}}$ Number in parentheses is the standard error for the value immediately above.

${ }^{\mathrm{e}}$ Calculated from yield and seed weight.

Table 3. Multiple regression coefficients relating disease development from $R_{2}$ to $R_{5}, R_{5}$ to $R_{6}$, and $\mathrm{R}_{6}$ to $\mathrm{R}_{7}$ to plot yield, 100 seed weight, and seed number per plot from soybean inoculated at various growth stages in microplots in 1992 and 1994, Fayetteville, Arkansas

\begin{tabular}{|c|c|c|c|c|c|}
\hline \multirow[b]{2}{*}{ Component } & \multicolumn{5}{|c|}{ Parameter } \\
\hline & Intercept & $R_{2}$ to $R_{5}$ & $R_{5}$ to $R_{6}$ & $R_{6}$ to $R_{7}$ & $\mathbf{R}_{2}$ \\
\hline \multicolumn{6}{|l|}{1992} \\
\hline $\begin{array}{l}\text { Yield } \\
\text { (g/plot) }\end{array}$ & $\begin{array}{l}164.97 \\
(0.0001)^{\mathrm{a}}\end{array}$ & $\begin{array}{l}-1.394 \\
(0.0001)\end{array}$ & $\begin{array}{c}-0.0814 \\
(0.0002)\end{array}$ & $\begin{array}{c}-0.2173 \\
(0.5857)\end{array}$ & 0.77 \\
\hline $\begin{array}{l}\text { Seed weight } \\
\text { (g/100 seed) }\end{array}$ & $\begin{array}{l}14.4175 \\
(0.0001)\end{array}$ & $\begin{array}{c}-0.0641 \\
(0.0001)\end{array}$ & $\begin{array}{c}-0.0594 \\
(0.0001)\end{array}$ & $\begin{array}{c}-0.0326 \\
(0.1614)\end{array}$ & 0.72 \\
\hline $\begin{array}{l}\text { Seed number } \\
\text { (number/plot) }\end{array}$ & $\begin{array}{c}1,204.965 \\
(0.0001)\end{array}$ & $\begin{array}{l}-7.6897 \\
(0.0004)\end{array}$ & $\begin{array}{l}-2.9295 \\
(0.1016)\end{array}$ & $\begin{array}{c}1.2782 \\
(0.7296)\end{array}$ & 0.58 \\
\hline \multicolumn{6}{|l|}{1994} \\
\hline $\begin{array}{l}\text { Yield } \\
\text { (g/plot) }\end{array}$ & $\begin{array}{r}286.127 \\
(0.0066)\end{array}$ & $\begin{array}{c}-2.7002 \\
(0.0096)\end{array}$ & $\begin{array}{c}-1.6864 \\
(0.0968)\end{array}$ & $\begin{array}{c}-2.2589 \\
(0.0583)\end{array}$ & 0.77 \\
\hline $\begin{array}{l}\text { Seed weight } \\
(\mathrm{g} / 100 \text { seed })\end{array}$ & $\begin{array}{c}18.7176 \\
(0.0158)\end{array}$ & $\begin{array}{c}-0.1261 \\
(0.0912)\end{array}$ & $\begin{array}{c}-0.0875 \\
(0.2411)\end{array}$ & $\begin{array}{c}-0.1143 \\
(0.1913)\end{array}$ & 0.50 \\
\hline $\begin{array}{l}\text { Seed number } \\
\text { (number/plot) }\end{array}$ & $\begin{array}{l}2,872.794 \\
\quad(0.0272)\end{array}$ & $\begin{array}{r}-26.4782 \\
(0.0400)\end{array}$ & $\begin{array}{r}-12.2957 \\
(0.3317)\end{array}$ & $\begin{array}{r}-22.0429 \\
(0.1405)\end{array}$ & 0.70 \\
\hline
\end{tabular}

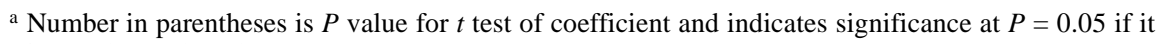
is equal to or less than 0.05 . development with exposure to inoculum after $\mathrm{V}_{10}$ and little or no disease with exposure to inoculum after $R_{2}$. In these experiments, they used infested debris as inoculum, so differences in disease development could be due to differences in environment or changes in the amount of inoculum produced during the season. Others have reported development of stem canker symptoms with inoculations at $\mathrm{R}_{2}$ or later $(9,19)$.

Yield was affected by the total amount of disease and also by when disease occurred. The significant effect of disease incidence between $R_{2}$ and $R_{5}$ growth stage on yield and seed number in both years was related to plant development. Pods develop between these growth stages, so disease occurring then would affect yield by precluding seed formation. Disease incidence that developed between $\mathrm{R}_{5}$ and $R_{6}$ significantly affected seed weight in 1992. During this period of $R_{5}$ to $R_{6}$, most of the seed mass is formed, so disease during this time would have its greatest effect on seed weight. High levels of disease at $R_{5}$ in 1994 probably reduced the effect of disease development from $R_{5}$ to $\mathrm{R}_{6}$ on this component of yield, as shown in the multiple regression equations.

These results indicate that, with the cultivar Walters, infection that leads to disease can occur over a long period of time and that foliar symptoms develop after both the onset of flowering $\left(\mathrm{R}_{2}\right)$ and a minimum incubation period. Foliar symptoms were closely related to yield loss. Further research is needed to determine the effect of cultivar on optimum time of infection, incubation period, and resulting disease development, and the effect of the environment on production of inoculum and symptoms. A more complete understanding of the epidemiology of stem canker could improve existing control measures and help in the development of new control measures for this important disease of soybean.

\section{ACKNOWLEDGMENTS}

This research was funded in part by a grant from the Arkansas Soybean Promotion Board.

\section{LITERATURE CITED}

1. Backman, P. A., Weaver, D. B., and MorganJones, G. 1985. Soybean stem canker: An emerging disease problem. Plant Dis. 69:641647.

2. Chambers, A. Y. 1993. Further evaluation of early-season fungicide sprays for soybean stem canker control. (Abstr.) Proc. Annu. Meet. South. Soybean Dis. Workers, 20th 20:30.

3. Damicone, J. P., Berggren, G. T., and Snow, J. P. 1987. Effect of free moisture on soybean stem canker development. Phytopathology 77:1568-1572.

4. Damicone, J. P., Snow, J. P., and Berggren, G. T. 1990. Spatial and temporal spread of soybean stem canker from an inoculum point source. Phytopathology 80:571-578.

5. Fehr, W. R., Caviness, C. E., Burwood, D. T., and Pennington, J. S. 1971. Stage development descriptions for soybeans, Glycine max (L.) Merr. Crop Sci. 11:929-931. 
6. Fernandez, F. A., and Hanlin, R. T. 1996. Morphological and RAPD analyses of Diaporthe phaseolorum from soybean. Mycologia 88:425-440.

7. Kirkpatrick, T. L. 1994. Preliminary results of the 1993 soybean disease screening program. Arkansas Coop. Ext. Serv., Misc. Publ.

8. Lalitha, B., Snow, J. P., and Berggren, G. T. 1989. Phytotoxin production by Diaporthe phaseolorum var. caulivora, the causal organism of stem canker of soybean. Phytopathology 79:499-504.

9. Pacumbaba, R. P. 1992. Effects of induced epidemics of Heterodera glycines, Diaporthe phaseolorum var. caulivora, and Pseudomonas syringae pv. glycinea in single inoculations or in combinations on soybean yield and other agronomic characteristics. J. Agron. Crop Sci. 169:176-183

10. Padgett, G. B., Snow, J. P., and Berggren, G. T. 1991. Southern stem canker epidemics: The infection window and the relationship between inoculation timing and yield of soybean. (Abstr.) Proc. Annu. Meet. South. Soy- bean Dis. Workers, 18th. 18:11.

11. Pioli, R., Gattuso, S., Prado, D., and Borghi, A. 1997. Recent outbreak of stem canker (Diaporthe phaseolorum var. meridionales) of soybean in Santa Fe, Argentina. Plant Dis. 81:1215.

12. Ploetz, R. C., and Shokes, F. M. 1985. Soybean stem canker incited by ascospores and conidia of the fungus causing the disease in southeastern United States. Plant Dis. 69:990992.

13. Russin, J. S., Betz, T. R., Padgett, G. B., and Snow, J. P. 1993. An inoculated nursery to screen soybean varieties for disease reactions in southern Louisiana. (Abstr.) Phytopathology 83:1407

14. Sciumbato, G. L., and Keeling, B. C. 1985. Effects of planting date and inoculation date on stem canker of soybeans. (Abstr.) Proc. Annu. Meet. South. Soybean Dis. Workers, 12th. 12:69.

15. Shaner, G., and Finney, R. E. 1977. The effect of nitrogen fertilization on the expression of slow-mildewing resistance in Knox wheat.
Phytopathology 67:1183-1186.

16. Smith, E. F., and Backman, P. A. 1989. Epidemiology of soybean stem canker in the southeastern United States: Relationship between time of exposure to inoculum and dis ease severity. Plant Dis. 73:464-468.

17. Snow, J. P., and Padgett, G. B. 1991. Evaluation of cultivars for stem canker resistance in an inoculated nursery. (Abstr.) Proc. Annu. Meet. South. Soybean Dis. Workers, 18th $18: 16$

18. Stuart, A., and Ord, K. J. 1994 Kendall's Advanced Theory of Statistics. 6th ed. Vol. 1: Distribution Theory. Edward Arnold, London.

19. Subbarao, K. V., Snow, J. P., Berggren, G. T. Damicone, J. P., and Padgett, G. B. 1992 Analysis of stem canker epidemics in irrigated and nonirrigated conditions on differentially susceptible soybean cultivars. Phytopathology 82:1251-1256.

20. Sutton, E. A., and Rupe, J. C. 1993. Infection timing and the development of stem canker in soybean. (Abstr.) Proc. Annu. Meet. South. Soybean Dis. Workers, 20th. 20:29. 